\title{
Transmission, Blood, Recipient/Donor
}

National Cancer Institute

\section{Source}

National Cancer Institute. Transmission, Blood, Recipient/Donor. NCI Thesaurus. Code C19079.

Passage or transfer, as of a disease, by blood transfusion from a donor individual to a recipient. $(\mathrm{NCl})$ 